\title{
nature
}

19 August 2004 Volume 430 Issue no 7002

\section{Passing the torch}

With the death of Francis Crick, biology is mourning one of its deepest thinkers. A work of futurology, published in 1970, reveals the extent of his prescience — and suggests challenges for today's theorists.

W hen Francis Crick and James Watson described the doublehelix structure of DNA in 1953, they charmed many with their unassuming pay-off line: "It has not escaped our notice that the specific pairing we have postulated immediately suggests a possible copying mechanism for the genetic material."

In fact, little in the broad landscape of biology escaped Crick's attention. The publication of his obituary (see page 845) marks a good time to revisit one of his lesser-known works, a 1970 essay in Nature on 'Molecular Biology in the Year 2000' (www.nature.com/nature/ focus/crick/pdf/crick228.pdf). Unlike most exercises in crystal-ball gazing, it holds up remarkably well to the scrutiny of hindsight.

Setting about his task with some trepidation, Crick divided biological problems into three categories: those that would be solved by the turn of the millennium; those that would have advanced considerably towards resolution; and the big questions that would still be taxing the best scientific minds.

In some respects, Crick overestimated the rate of progress. We are still some way from a complete understanding of the significance of repetitive 'junk' DNA; much the same can be said for the sequences that regulate gene expression. But, as he predicted, the replication of DNA and the structure of chromosomes are now well documented.

Crick's choices for the second category were similarly prescient. Some problems fell more easily than he expected: apart from minor details, the mechanism of muscle contraction can be considered solved. Others, such as "the nature of the influences which produce 'gradients' in embryological development", have proved more complex. But his list represents a remarkably accurate summary of the issues that have occupied biologists over the past three-and-a-half decades — not all of which would have been obvious back in 1970 .

As for the final category of unsolved problems, we're still wrestling with the origins of life on Earth, and whether life exists on other worlds. The nature of consciousness - to which Crick devoted his later years - similarly remains shrouded in mystery.

Crick also had some observations about the future of this journal. "I hope," he wrote, "that Nature will not become overloaded with too many detailed papers in what we now regard as the more classical parts of molecular biology."

In terms of what was then seen as "classical", Crick's wish has been granted. But in recent years, there's no denying the preponderance of Nature papers on the molecular details of such topics as signal transduction and the cell cycle. Crick would probably have been disappointed by the relative paucity of great contributions on the origins of life, and astrobiology. In part, this may reflect a conservative system of research funding that discourages biologists from attempting the high-risk imaginative leaps that Crick favoured. But it's also a reflection of the nature of the beast. Crick's essay hinted at this: "Problems involving complex interactions can hardly be avoided, since some of the most profound aspects of biology are of this character."

Crick understandably failed to predict the rise of high-throughput techniques, including whole-genome sequencing, DNA microarray analysis and proteome profiling. These techniques have confirmed, if there was any doubt, that the details of biology are truly devilish.

In the wake of genomics, the emerging discipline of systems biology has the potential to make sense of these details, by treating genes and proteins as networks, ripe for theoretical analysis. There's reason to hope that theorists will soon be able to advise lab-based biologists on where to look for answers, much as theoretical physicists predicted the existence of fundamental subatomic particles a generation ago.

Molecular biology is easily dismissed as a book of recipes, and too many of its practitioners allow this criticism to pass unchallenged. Crick would not have wanted this to happen. Let's hope his legacy of thinking big lives on.

\section{Let's blame Canada}

Americans should worry less about their neighbour and more about the prestige of regulators who protect public health.

ester Crawford, acting commissioner of the US Food and Drug Administration (FDA), is worried that the importation of cheap pharmaceuticals could expose Americans to attack from bioterrorists. In an interview with the Associated Press on 11 August, he raised the potential contamination of imported drugs as a threat to national security.

In practice, the imports come mainly from Canada, where drugs are subject to government price controls. They are increasingly sanctioned by state governments in the United States, where citizens are tiring of paying inflated prices for medicines. The Bush administration - taking its cue from US drug companies — would like to close the door to such imports.

As that acclaimed documentary the South Park movie demonstrated, the United States' paranoia about its threatening northern neighbour is richly justified. But Canadian perfidy must not blind Americans to a starker domestic threat: the degeneration of once- prestigious federal agencies, such as the FDA, into political poodles.

The FDA has an inspiring history. Its record of stalwart independence is one of the reasons Americans have such high confidence in the safety of both their pharmaceuticals and their food supply. Only a few years ago, for example, FDA commissioner David Kessler launched an audacious effort to regulate tobacco as a drug. Congress opposed the move and Kessler received little support from his bosses in the Clinton administration. But his stand, for a while, had 'big tobacco's shaking in its boots.

Today, the chances of such an initiative originating within the FDA itself are slight — not much larger than the chances of someone choosing to terrorize the US public by contaminating a shipment of drugs before their export from Canada. It is scandalous that the FDA's leadership seems ready to make politically motivated pronouncements that link two serious issues - drug pricing and bioterrorism — in a manner likely only to inflate public cynicism about both. 